\title{
粘性土のコーン指数と切削抵抗について \\ ON THE RELATION BETWEEN CONE INDICES AND CUTTING RESISTANCES OF COHESIVE SOILS
}

$$
\begin{array}{ll}
\text { 畠 } & \text { 昭 治 郎* } \\
\text { By } & \text { Shojiro Hata }
\end{array}
$$

\section{1. 緒言}

建設施工における土質調查の重要性はもはや論をまた ぬとてろであり，その奥否が施工能率，成果および工費 におよぼす影響はきわめて大である。とくに，軟弱土質 の多いわが国に打いては，基礎の支持力計算や施工機械 の運営に関して, 粘性土の強度を適確に, 速やかに知ら なければならない。この粘着強度を現場で測定する方法 としては, 現在, 円錐貫入試験機およびベーンせん断試 験機が最も多く用いられている。なかでも, 円錐貫入試 験は, その操作が䧳単で, 粘性土に対しては比較的安定 した值を与えること，およで地表面の独度測定に便利で あることのために, 施工機械の分野において, 掘削性能 および通過性能（トラフィカビリティ）の判定にひろく 用いられている。

円錐貫入試験法の原理はきわめて簡単であり，一定頂 角および一定底面積を有する円錐体を，一定の低速度で 土中に圧入し，そのときの圧入抵抗を底面積で除した值 を求めて，てれをもってコーン支持力あるいはコーン指 数とするものである。この円錐頂角は $90^{\circ}, 60^{\circ}, 30^{\circ}$ な ぞ, 種々のものが使用されているが, コーン強度測定值 は頂角によってあまり大きい影響をうけないようであ る。測定方法にも種々考察が加えられ, 最初は, コーン に直接ロッドをとりつけ，そのロッドの上端に，圧力㖕 を通して荷重を加光，コーン支持力を読みとるものであ ったが, その後, ロッドを 2 重にして, 側面摩摖を除い たもの，圧入抵抗を電気的にとりだし，自記させるもの など，多くの種類がある。また，側面摩摖を独立に测定 するために，特殊なスリーブを用いたものもある。この ように，現在まで，多くの夷测が行なわれたが，それら を総括して,つぎの実験式が成立するといわれている1)。 すなわち,

$$
\frac{Q}{A}=q_{c} \doteqdot(10 \sim 11) c\left(\mathrm{~kg} / \mathrm{cm}^{2}\right)
$$

ここで, $Q$ はコーン貫人抵抗， $A$ はコーン底面積， $q_{c}$ はコーン指数， $c$ は粘土の粘稙拄さである。てれを用い れば,コーン試験によって, 粘土の粘着㤝さを簡単に求 めることができ，種々の計算に便利である。

一方, 著者らはさきに土の切削治度試験方法を提案

* 正会員 工博 京都大学助教授 工学部土木工学教室
し，その測定值からその土の切削抵抗を算出する方法を 述べた 2)。乙れは, 幅 $50 \mathrm{~mm}$, 厚さ $3 \sim 10 \mathrm{~mm}$ の平鋼 板を, 鉛直に保ちながら深さ $t \mathrm{~cm}$ まで土中に押込み, 地表面上に固定支点を設けてこの鋼板をささえ，その上 端を引張って, 土を破壊させたときの, 所要転倒モーメ ントを測定して, 切削強度指数 $e_{s}$ を次式より求めるも のである。

$$
e_{s}=\frac{M}{B t^{3}}\left(\mathrm{~kg} / \mathrm{cm}^{3}\right)
$$

ここで， $M$ は所要最大転倒モーメント， $B$ は鋼板幅で 市る。乙の切削溞度指数 $e_{s}$ は, 切削抵抗にほぼ正比例 しており,またその比例係数が土質の変化にかかわら ず，ほぼ一定であるということが実験によって確かめら れており ${ }^{3)}$ ，土の切削抵抗算出のためにはきわめて便利 な值であるが，測定方法が簡単ではあるが余程注意深く 行なわないと誤差が生じやすいとと，および，試験深さ $t$ を種々に変えてそれぞれ数回の測定を必要とするてと など，操作上の難点と，固いよくしまった土の場合に は，鋼板を押込むときにまわりの土をゆるめてしまうと いう久点があり，一般に用いられるに至っていない。そ れゆえ, 本文においては, 粘性土（内部摩擦角は無視で きるものとする) について, コーン指数と切削強度指数 との関係を, 粘着強さの関数として理論的, 実験的に究 明し，土の切削抵抗を，コーン指数を用いて計算できる ようにしたものである。

\section{2. コーン指数 $\boldsymbol{q}_{\boldsymbol{c}}$}

円錐貫入試験状態を観察すると, 地表面における貫入

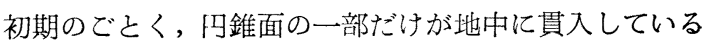
埸合と，円錐部が底面まですでに地中に貫入してしまっ ている場合との 2 つわけることができる。前者を初期 貫人状態, 後者在定常貫入状態と呼ぶこととする。

初期貫入状態は, 地表面の強度測定時に多く現われ, 定常貫入状態は，地中やや深部の測定時，いわゆるサウ ンディング時に必らず見られる現象である。まず, 初期 貫入について述ぐる。

\section{(1) 初期貫入状態}

図一1に，との状態における円錐周辺の粘土の滑り線 図を示す。簡単のため, 円錐面は十分滑らかで,貫入中, この面では直圧力のみが作用し, 摩擦力は無視できるも 
Fig. 1 Slip-line net work in soil at the beginning of penetration of the cone.

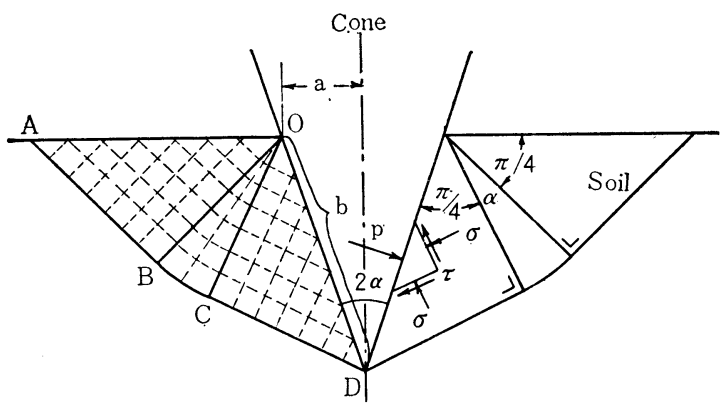

のと仮定する。 また，貫入深さ Fig. 2 Equilibrium on the が小さく, 粘土 の単位重量は, 粘着強さに比較 して無視できる ものと考える。 実測の際観察さ れるように,円 錐部が貫入した とき, 地表面の 盛上りは見られ free surface.

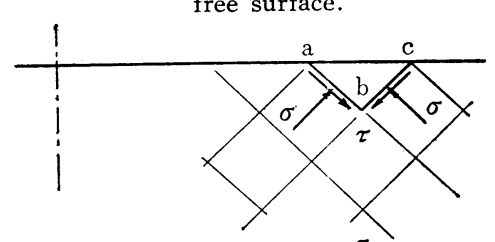

ない。図において, 領域 ODCは, 土と円錐面との接触 部 $\mathrm{OD}$ 上に摩擦が作用せぬから, OD 面と $45^{\circ}$ で交わ る 2 組の直交滑り線群からなる。領域 $\mathrm{OAB}$ は土の受動 限界平衡状態（内部摩擦角が 0 であるから，滑り線の傾 きは水平と $45^{\circ}$ をなす直交直線となり, 受動, 主動の区 別はない）に対応する部分である。領域 OBC はこれら 2 領域をつなぐ部分で, 円弧および半径方向の滑り線と なる。つぎに各部分の応力状態を調べる。

領域 $\mathrm{OAB}$ : 図一2 に示すように, 地表面と両滑り面 で囲まれた, 微小三角形 $\mathrm{abc}$ には, 垂直応力 $\sigma$ とせん 断応力 $\tau$ とが作用している。ac 面は地表面であるから この面に作用する直応力およびせん断応力はともに0で あり，てれらの力のつりあいから， $\sigma=\tau$ がえられる。 そして純粘土においては, ては限界平衡時には粘着強さ $c$ に等しい。したがって $\sigma=c$ (一定) となる。ただし， 乙の垂直応力 $\sigma$ は, 鉛直方向主応力 $\sigma_{1}$ と, 水平方向主 応力 $\sigma_{3}$ との平均值である。すなわち

$$
\sigma=\frac{\sigma_{1}+\sigma_{3}}{2}
$$

いま, $\sigma_{1}=0$ であるから, $\sigma_{3}=2 \sigma=2 c$ となる。

以上は，平面ひずみ状態において成立するもので，乙 の場合は，図一2 下部に示すように，極坐標となり，面 $a b$ と面 bc の面積は等しくない。したがって両面に作用

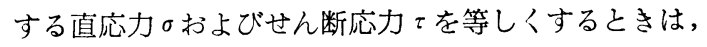
$r$ 方向のつりあいがとれないてとになる。しかし，滑り
線にそう最大せん断力は, その位置のいかんにかかわら ず常に粘着強さに等しいはずであるから， $\sigma=\tau=c$ はこ の領域のどの点においても成立しなければならない。何 となれば,この領域は軸対称であるから,図に示したせん 断応力以外のせん断応力はすべて 0 になる。それで, bc 面で $\sigma \neq \tau=c$ となったとしても, ての応力差につりあ うべき鉛直方向応力はどてにも存在しないからである。 このように, 各部で $\sigma=\tau=c$ が成立つとすれば, その $r$ 方向の力の差につりあうべきものは, 中間主応力 $\sigma_{2}$ 以 外にはない。これより，

$$
\begin{aligned}
2 \sigma_{2} \frac{d r}{2} \frac{d r}{2} d \theta= & (\sigma+\tau) \cos \frac{\pi}{2} \\
& \times\{(r+d r)-r\} d \theta \frac{d r}{2} / \cos \frac{\pi}{2} \\
= & (\sigma+\tau) \frac{d r}{2} d r d \theta \\
\therefore \quad \sigma_{2}=\sigma+\tau= & \sigma_{3}
\end{aligned}
$$

結局, 図一1 のように, 滑り線を仮定したというとと は, その前提として, 中間主応力はどちらか一方の主応 力に等しいということを仮定しているととになる( きが, 図一2 の逆方向のときは， $\sigma_{2}=\sigma-\tau=\sigma_{1}$ となる)。 この仮定を用いれば, 軸対称問題が平面ひずみ問題とま ったく同等になるから, 以後は平面ひずみ問題として解 析してゆく。

さて地表面 $\mathrm{OA}$ 上のすべての点において $\sigma=\tau=c$ が 成立すると, この領域 $\mathrm{OAB}$ は直線滑り線であるから, ての全領域で $\sigma=\tau=c$ が成り立つ（自重を無視している から)。したがって，境界 $\mathrm{OB}$ 上でも $\sigma=\tau=c$ となる。

領域 OBC：曲線滑り線にそってつぎの方程式が成り 立つととが知られている4。

$$
\sigma+2 c \theta=\text { const. }
$$

ここで， $\theta$ は滑り線の水平となす角である。したがっ て，境界 $\mathrm{OB}$ 上では，

$$
\sigma+2 c \theta=c+2 c \frac{\pi}{4}=c\left(1+\frac{\pi}{2}\right)
$$

境界 OC 上では

$$
\begin{aligned}
& \sigma+2 c\left(\frac{\pi}{4}-\alpha\right)=c\left(1+\frac{\pi}{2}\right) \\
& \therefore \sigma=c(1+2 \alpha) \cdots \cdots \ldots \ldots . .
\end{aligned}
$$

ここで, $2 \alpha$ は円錐の頂角である。

領域 OCD : ことは領域 OAB と同様に直線滑り線で あるから，全領域内でのは一定である。したがって円錐 表面 OD に作用する力は 図一1 のようになる。これよ り, 円錐面に㗢く直圧力を $p$ とすれば,

$$
\sqrt{2} p=\frac{2}{\sqrt{2}}(\sigma+c) \quad \therefore p=\sigma+c
$$

式 (4) を用いて

$$
p=2 c(1+\alpha)
$$

これより, 貫入全抵抗 $Q$ は 
$Q=p A_{c} \sin \alpha$

$A_{c}:$ 円錐の貫入部分表面積

錐の接地部分の半径を $a$, 買入母線長を $b$ とすれば

$$
\begin{aligned}
& A_{c}=\pi b^{2} \frac{a}{b}=\pi a b=\frac{\pi a^{2}}{\sin \alpha} \\
& \therefore Q=\pi a^{2} p \\
& \therefore q_{c}=\frac{Q}{\pi a^{2}}=p=2(1+\alpha) c
\end{aligned}
$$

となり, 結局, コーン指数は, 円錐面に働らく垂直応力

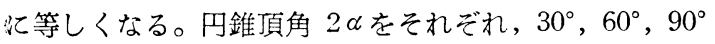
にとったときのコーン指数はそれぞれ，2.52 c， $3.06 \mathrm{c}$, $3.57 \mathrm{c}$ となる。

\section{（2）定常貫入状態}

前と同様にして求めた滑り線図を 図一3 に示す。

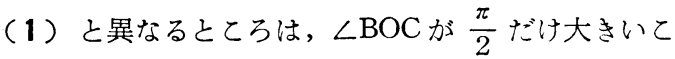
とであるから，境界 OC 上で

$$
\begin{aligned}
& \sigma-2 c\left(\frac{1}{4} \pi+\alpha\right)=c\left(1+\frac{\pi}{2}\right) \\
& \therefore \sigma=c(1+\pi+2 \alpha) \quad \cdots \cdots \cdots
\end{aligned}
$$

となる。したがって円錐面への直応力 $p$ は

$$
p=\sigma+c=2 c\left(1+\frac{\pi}{2}+\alpha\right)
$$

Fig. 3 Slip-line net work in soil at the stationary penetration of the cone.

となって，これがそのまま コーン指数 $q_{c}$ を表わす。

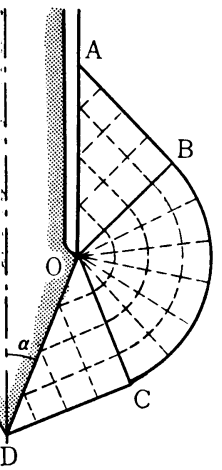

円錐頂角 $2 \alpha=30^{\circ}, 60^{\circ}, 90^{\circ}$ に対するコーン指数はそれ ぞれ，5.66 c, $6.20 \mathrm{c}, 6.71$ cとなり，乙れは最初にあ げた実験式（1）に比較し て約半分である。

この差は, 実際の円錐面 が十分滑らかではなく，粘 土との間に摩擦抵抗が働ら くことに起因すると考えら れる。

Fig. 4 Slip-line net work with surface friction of the cone.

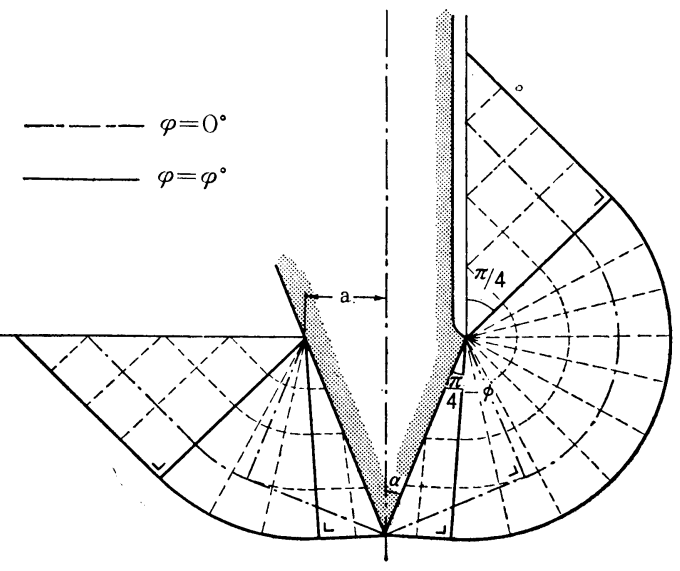

\section{（3）円錐面が滑らかでない場合}

円錐面と粘土の間の摩擦角を $\varphi$ とすれば，滑り線場 は図一4のようになり，式(4)および(7)はそれぞれ，

初期貫入 : $\sigma=c(1+2 \alpha+2 \varphi)$

定常貫入 : $\sigma=c(1+\pi+2 \alpha+2 \varphi)$

となる。円錐酌に作用する力は図一5 のようになり,乙 れより，円錐䝿入抵抗を計算すればつぎのようになる。

$$
\begin{aligned}
& p=\sigma+c \sin 2\left(\frac{\pi}{4}-\varphi\right) \cdots \cdots \text { 円錐面への直応力 } \\
& \tau=c \cos 2\left(\frac{\pi}{4}-\varphi\right) \cdots \cdots \cdots \cdots \text {. 錐面上のせん断応力 }
\end{aligned}
$$

定常貫入 : $q_{c}=p+\tau \cot \alpha$

$$
\begin{aligned}
= & \left\{1+2 \alpha+2 \varphi+\pi+\sin 2\left(\frac{\pi}{4}-\varphi\right)\right. \\
& \left.+\cos 2\left(\frac{\pi}{4}-\varphi\right) \cot \alpha\right\} c \cdots \cdots \cdots
\end{aligned}
$$

右包第 4 項の $\pi$ は，初期 貫入のときは除く。 $\alpha を$ $15^{\circ}, 35^{\circ}, 45^{\circ}$ としたと き, 種々の $\varphi$ に対する $q_{c} / c$ の值を図一6 に示 す。これをみれば， $\alpha=$ $15^{\circ}, \varphi=45^{\circ}$ の場合を除 いて, $q_{c} / c$ の值が 10 を 越えるものはなく,なお， 実験式(1)よりかなり小 さい。これは, 自重を無 視したこと，および粘土 の内部摩摖角を 0 とした ためであろうと考えられ る。実際の粘比やシルト では, 内部摩擦角は 0 と
Fig. 5 Forces on the cone surface.

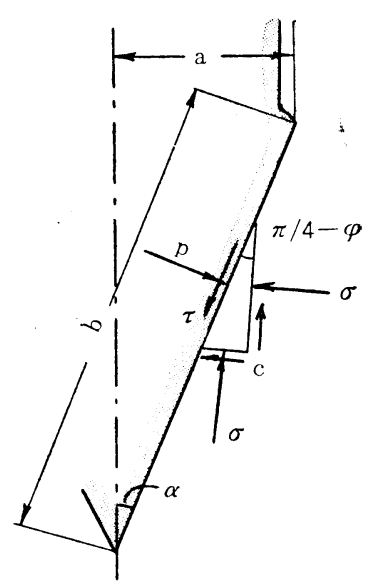
はならないことがある。この場合についての解析は後の 機会にゆずることとする。

以上で, 近似解ではあるが, 式 ( 1 )の係数の意味を明

Fig. 6, $q \mathrm{cc}$ and Friction on the cone surface.

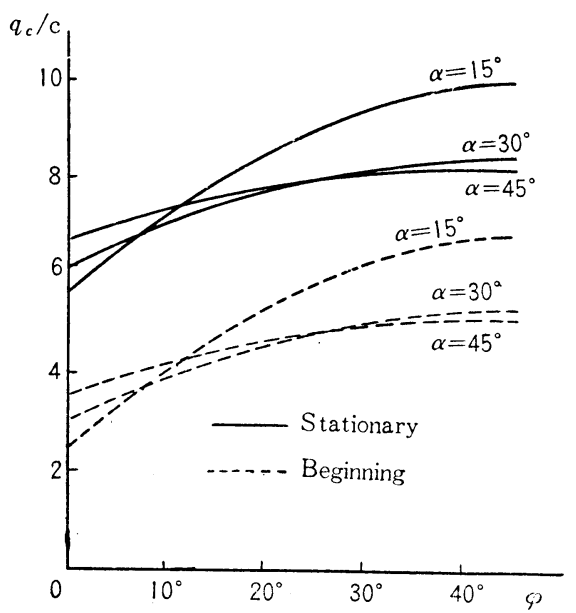


らかにした。

\section{3. 切削強度指数}

切削強度試験は前述のように，幅 $B$, 長さ $l$ の鋼板を 深さtだけ地中に押込み，地表上の支点のまわりにたお して，そのときの最大モーメントを測定するものであ る。いま，鋼板前面の土の破壊状態をみると 図一7（側 面図）および図一8 (上面図) のようになる。てれらの 考察より，板前面の土のすべり面を，図一9 のように仮 定する。図の妨りぶした部分は, 高さ $B$, 半径 $t$ の円 筒の $1 / 4$ のものであり，乙れが板前面についたまま，一 体となって抜け上るものと考元る。したがって，てれに 㗢らく抵抗は，内部摩擦角が 0 とすれば，円周面に作用 する単位面積当り $c$ なるせん断抵抗のみである。

ての $1 / 4$ 円筒体の両側面にあって，てれに引きずられ

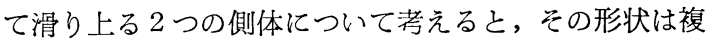
雑であるが，その両側滑り面に働らく力はやはり $c$ のみ である。ての滑り曲面上に働らく力の鉛直面内の分力の みが，鋼板の転倒モーメントに影響をおよぼすが，てれ は $1 / 4$ 円筒体の側面にせん断応力 $c$ が作用した場合と全 く同じである，乙れらの考察より，まず円周面に作用す るせん断抵抗モーメント $M_{1}$ は，

Fig. 7 Slip body in front of the testing plate.

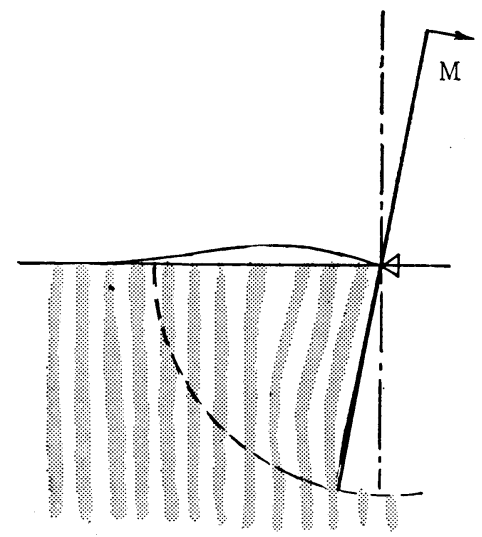

Fig. 8 Boundarline of slip body in free surface.

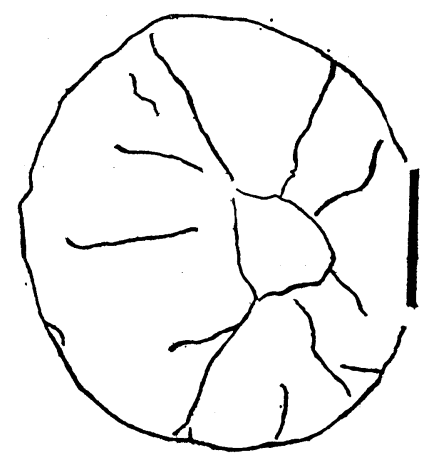

Fig. 9 Slip body in front of the festing plate.

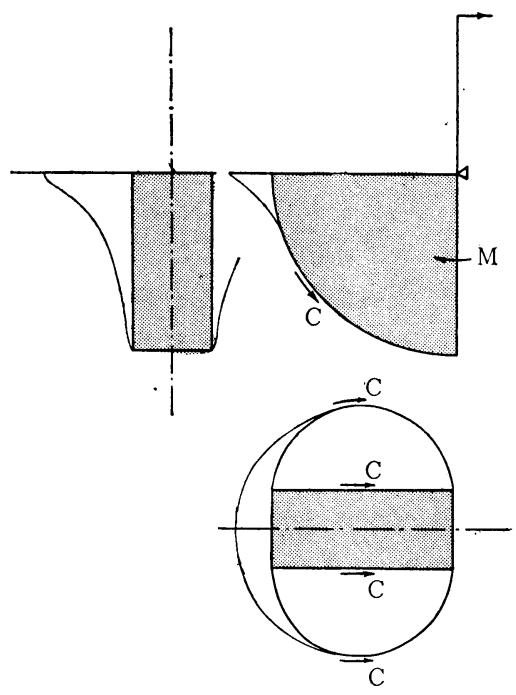

$$
M_{1}=c-\frac{\pi}{2} B t^{2}
$$

片側側面に作用するモーメント $M_{2}$ は，

$$
M_{2}=\int_{0}^{t} c \frac{\pi}{2} r d r \cdot r=c \frac{\pi}{6} t^{3}
$$

ゆえに全抵抗モーメント $M$ は，

$$
M=M_{1}+2 M_{2}=c \pi t^{2}\left(\frac{B}{2}+\frac{t}{3}\right) .
$$

また，

$$
e_{s}=\frac{M}{B t^{3}}=c \pi\left(\frac{1}{2 t}+\frac{1}{3 B}\right)
$$

となるから，切削強度指数 $e_{s}$ は $t$ および $B$ 亿逆比例す る項からなることがわかる。

また，

$$
e_{s} t=\frac{M}{B t^{2}}=c \pi\left(\frac{1}{2}+\frac{t}{3 B}\right)
$$

となり, この值は $t \ll B$ の範囲ではほとんど一定であ るととがわかる。

\section{4. 実験方法および結果}

\section{(1) 円錐貫入試験}

ここで用いたものは, 円錐頂角 $2 \alpha=60^{\circ}$, 底面断面積 $A=30 \mathrm{~cm}^{2}$ および $7 \mathrm{~cm}^{2}$ の 2 種を用いた。前者は電気 的に自記させるもの, 後者は直読式のものであり, 定常 貫入值は前者を, 初期貫入值は後者を用いて測定した。 測定結果の一例を 図一10 に示す。用いた粘土は, 四日 市海岸の地面下 $20 \mathrm{~m}$ 内外の沖積層粘土である。図の ように，

定常值 $q_{c}=\frac{10}{1.6} q_{u} \doteqdot 6.5 q_{u}=13.0 \mathrm{c}$

初期值 $q_{c}=\frac{4.2}{1.0} q_{u} \doteqdot 4.2 q_{u}=8.4 \mathrm{c}$ となり，式(1)より係数は少し大きくなっている。 
Fig. 10 Relations between $q_{c}$ and $q_{u}$

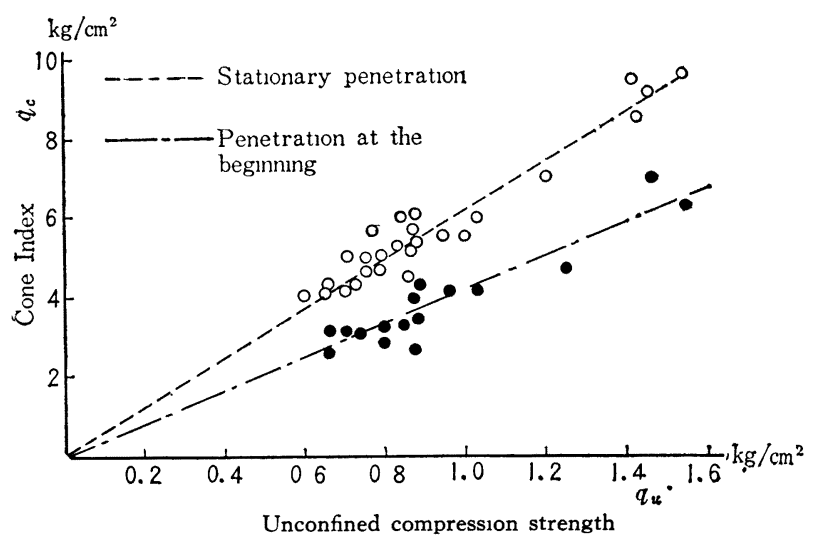

いる場命や，てていなくとも貫入尿さか线いとき には, $k$ の值は 0.1 よりも文い值をとるへき である。その值は，著者の行なった実験の範囲て は，0.15 付近をとるへきであると考えられる。

つぎに，刃幅 $B_{1}$ の刃を，深さ $t_{1}$ たけ入れた ときの, 水平切削抵抗 $H_{0}$ は, 粘性土に対して次 式て与えられる”。

$$
H_{0}=182 e_{s} t_{1}^{2} B_{1}
$$

たたし，てのときの $e_{s}$ は深さ $t=t_{1}$ の場合の值 を用いるものとする。上式に式 (13) を代入すれ ば,

$$
H_{0}=182 \pi k q_{c}\left(\frac{t_{1}}{2}+\frac{t_{1}{ }^{2}}{3 B}\right) B_{1}
$$

\section{（2）切削強度試験}

板幅 $B=1,2,3,5 \mathrm{~cm}$ の試験板を用い, 深さ $t$ を 1 $15 \mathrm{~cm}$ まで種々に変えて実測した。その結果を龱一11に 示す。用いた粘土の粘着力 $c$ は $0.10 \sim 0.20 \mathrm{~kg} / \mathrm{cm}^{2}$ であ った。式(12)にしたかって叶算した值を，図中破線で表 わしておいた。ての場合には, 実测值と計算值とはよく 一致している。

Fig. $11 e_{s} t / c$ and $t / B$

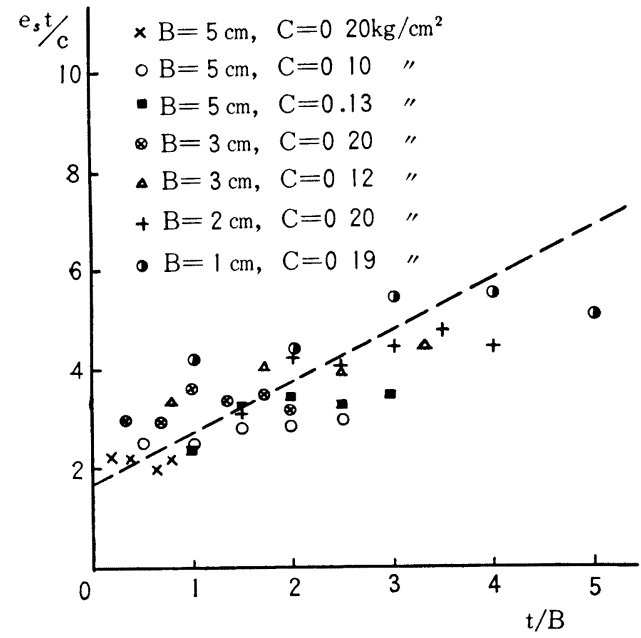

\section{5 コーン指数亡切削抵抗亡の関係}

以上のべてきたてとから, 内部摩擦角を 0 と考えるこ 々かでるような土に対しては, 粘着力 $c$ を仲介として コーン強度 $q_{c}$ と切削強度 $e_{s}$ とは一義的な関係をもつ ことかわかった。すなわち, 式( 1 )と式(11)から

$$
e_{s}=\pi k q_{c}\left(\frac{1}{2 t}+\frac{1}{3 B}\right) \ldots \ldots .
$$

となる。こてて $k=c / q_{c}$ て, この值は現在のとてろ, 厳 密な理論值は得られす, 実験係数を用いなけれはならな い。一般に行なわれている, $k=01$ というのは, 定常貫 入状態に対するものてあって，地表面のでく近くで，円 錐貫入試験を行なうとき, 円錐底面かまた地表面にてて
ここで，Bは常に $5 \mathrm{~cm}$ とすれば，

$$
H_{0}=182 \pi k\left(\frac{1}{2}+\frac{t_{1}}{15}\right) B_{1} t_{1} q_{c}
$$

いま, $k=015$ とすれば，

$$
H_{0}=0858 q_{c} B_{1} t_{1}\left(\frac{1}{2}+\frac{t_{1}}{15}\right) \cdots . .
$$

となり,コーン指数から切削抵抗を推定しうる。

\section{6 結 語}

本文においては, 従来, 土の切削抵抗を求めるための 強度指数を測定する方法か，種々であり，実施上不便多 きととを考え, 最もひろく行なわれている円錐貫入試験 をもって代表させるために,種々究明を行なった。ます, 円錐貫入試験によって求められるコーン指数（コーン支 持力）の物理的意義を明らかにしよとうしたか，てれは 理想的な場合の他は解析困難であった。しかし，コーン 支持力には，円錐の貫入度加线い，いわゆる初期貫入状 態におけるものと,深く貫入した, 定常貫入状態における ものとでは, 等しい粘着力をもつ粘性土に対しても, そ れそれ異なる值をとるへきてあるてとを指摘し，一般に 用いられている「コーン支持力は粘着力の10倍」というの は,定常貫入状態に対応するものであることを推論した。

つきに，切削抵抗と直線関係にある，切削強度指数を 解析し, これが, 粘土の場合にはその粘着力の関数とし て, 純理論的に導き出されることを明らかにし，切削強 度と切削抵抗の間に存在する実験式をもととして, 切削 抵抗とコーン指数との関係式を求めるてとかてきた。

このように，一応の結果を得たか，乙の問題にはなお 問題点か多数あり，とくに，内部摩摖角を有する土に対 してどう取扱うかは今後の問題てあり，いっそう研究を 進めたいと考えている次第てある。

\section{参 考 文 献}

1）土質工学会 土質試験法解说 (第 2 集), p 2191961

2) 村山・畠 土木学会詰, 40-3, p 951955

3) 前掲 2)

4) Hill, R The Mathematical Theory of Plactivity, 1950

5）畠 建設の機械化，135, p 711961

(1964 2 4 ·受付) 